\title{
EFFICACY OF THREE INSECTICIDES FOR CONTROLLING CORN EARWORM, Helicoverpa zea (BODDIE) IN MAIZE
}

\author{
M. A. Uddin, M. Jahan, M. M. Uddin and M. M. Rahman \\ Department of Entomology, Bangladesh Agricultural University \\ Mymensingh-2202, Bangladesh
}

\begin{abstract}
A field study was conducted to test the efficacy of three insecticides viz. Dursban 20 EC, Decis 2.5 EC and Lebaycid 50 EC with three different doses @ $0.1 \%, 0.2 \%$ and $0.3 \%$ in controlling the Helicoverpa zea in maize (cv. BARI Hybrid Bhutta-5) at Entomology Field Laboratory, BAU, Mymensingh. The results showed that the lowest percent of cob infestation was $1.72 \%, 1.90 \%$ and $2.75 \%$ at 3 DAT, 7 DAT and 12 DAT in $0.3 \%$ Decis treated plots, respectively. The highest percent of cob infestation was observed in untreated plots. The lowest mean number of kernel damage (2.10) and yield loss $(1.40 \mathrm{~kg} / \mathrm{ha})$ were found with $0.3 \%$ Decis $2.5 \mathrm{EC}$ treated plots. The efficacy of insecticides were Decis $2.5 \mathrm{EC}$ $(0.3 \%)>$ Decis 2.5 EC $(0.2 \%)>$ Dursban 20 EC $(0.3 \%)>$ Lebaycid 50 EC $(0.3 \%)$. The efficacy of all insecticides on cob infestation at different time intervals indicated that insecticidal toxicity decreases with the increasing time after application.
\end{abstract}

Key words : Efficacy, Insecticides, Helicoverpa zea, Maize, Yield loss

\section{INTRODUCTION}

Maize is one of the important cereal crops in Bangladesh. Mathur (1987) observed that over 250 species are associated with maize in the field and storage conditions. Of these, 74 species have appeared recently and about a dozen are of potential economic importance (Mathur, 1992). Among them corn earworm is the most important constraint to corn production. The larva is mainly responsible for causing damage. It is polyphagous in nature and attacks more than 182 plant species, including cotton, chickpea, cowpea, pigeon pea, peas, sunflower, sorghum, groundnut, field beans, tomato, tobacco, maize and a range of vegetables, fruit crops and tree species. Annual yield loss ranged from 5-7 percent in field and 10-15 percent corn for human consumption (Bell and McGeoch, 1996).

Farmers around the world use chemical pesticides to control Helicoverpa. Chemical control has been the most widely used and generally most successful method to control the pests on the most crops when judiciously used, especially for crops such as maize and high value crops (Hill, 1983; Luttrell et al., 1994). Chemical control becomes a necessity if a significant number of eggs and young larvae are present on seedlings and fruiting bodies of the crop, with timely insecticide application being targeted at these stages of pest management (Mueller et al., 1984; Flint, 1985). Several insecticides from endosulfan to 
synthetic pyrethroids and insect growth regulators have been demonstrated to give effective control of Helicoverpa (Sehgal and Ujagir, 1990). Filho et al. (2002) reported that chlorpyrifos gave effective control of $H$. zea in maize for 21 days after insecticide application

Resistance to insecticides is widespread, particularly in crops where pyrethroids are used frequently (Greenstone, 1995; Kanga et al., 1995). Pesticides manufacturers have produced more potent and toxic pesticides whenever Helicoverpa developed resistance to the prevailing insecticides. But due to the cryptic feeding behavior of Heliothis, it is often difficult to provide a complete cover. This behavior may partly explain why insecticide resistance has become so widespread (Luttrell et al., 1994). This vicious cycle has led to a stage where Helicoverpa has developed resistance to most of the available pesticides, especially to synthetic pyrethroids. However, pesticides need to be critically used and monitored to prevent the development of resistance to insecticides. It has, therefore, become very important to find out the efficacy of commonly used insecticides to control Helicoverpa sp. (Sharma, 2001). With this view an experiment was undertaken to determine the efficacy of three insecticides in controlling corn earworm in maize at BAU campus.

\section{MATERIALS AND METHODS}

The efficacy of three insecticides viz. Dursban, Decis and Lebaycid each with three doses $(0.1,0.2$ and $0.3 \%)$ against corn earworm, H. zea was studied in the Entomology Field Laboratory, Bangladesh Agricultural University, Mymensingh from November 2008 to May 2009. The experiment was carried out in randomized complete block design (RCBD) with three replications. BARI Hybrid Bhutta-5 was used as test crop.

Insecticide treatments were applied as spray when corn was at the raw tassel stage of development and ears were starting to show silk emergence. Insecticides were applied with a Knapsack hand pressurized sprayer with nozzle boom aimed at ear region of corn plant. Spraying was done at 4.30 p.m. to avoid bright sun and drift caused by strong wind.

There were three blocks and six sub-blocks and each sub-block was divided into ten plots. There were 96 plants per plot. The number of total cobs was counted individually before and after application of each insecticide treatments at 3, 7, and 12 DAT (days after treatment). Then mean and total numbers of cobs were counted. The infested cobs were counted from each plot at every pre and post application of insecticide treatments. Total and mean numbers of infested cobs were counted in the same way. The percentage of damage was determined by counting the number of total cob and infested cob per plot before and after application of insecticide. The percentage of cob damage was calculated using the following formula :

$$
\% \text { cob damage }=\frac{\mathrm{P}_{0} \times 100}{\mathrm{P}_{\mathrm{r}}}
$$


Where,

$$
\begin{aligned}
& \mathrm{P}_{0}=\text { Number of infested cob/plot } \\
& \mathrm{P}_{\mathrm{r}}=\text { Total number of cob/plot }
\end{aligned}
$$

The recorded data were compiled and tabulated for statistical analysis. Analysis of variance was done with the help of computer package MSTAT-C. The mean differences among the treatments were analyzed using LSD (Gomez and Gomez, 1984).

\section{RESULTS AND DISCUSSION}

\section{Efficacy of different insecticides on the cob infestation at different time intervals}

The efficacy of three insecticides was evaluated at 3 DAT, 7 DAT and 12 DAT intervals and the results are presented in Table 1 . At 3 DAT, the lowest cob infestation was $1.72 \%$ in Decis $0.3 \%$ treated plots and the highest mean percent cob infestation was $6.00 \%$ in control plots followed by $5.35 \%$ and $5 \%$ in $0.1 \%$ Lebaycid and $0.1 \%$ Decis treated plots, respectively. At $7 \mathrm{DAT}$, the highest mean cob infestation was $7.05 \%$ in control plots and The lowest percent cob infestation was $1.90 \%$ in Decis $0.3 \%$ treated plots. The second and third lowest cob percent infestation was 3.5\% in $0.2 \%$ Decis and $4.25 \%$ in $0.3 \%$ Lebaycid treated plots, respectively. After applying insecticides at $12 \mathrm{DAT}$, the lowest mean percent cob infestation was $2.75 \%$ in $0.3 \%$ Decis treated plots and the highest cob infestation was $7.50 \%$ in control plots followed by $6.97 \%$ and $6.85 \%$ in $0.1 \%$ Decis and $0.1 \%$ Lebaycid treated plots, respectively. In the control plots the highest cob infestation was observed with different time intervals. The results showed that the cob infestation varied significantly at different time intervals with different concentrations of insecticides.

Table 1. Effect of three insecticides on the cob infestation at different time intervals

\begin{tabular}{l|c|c|c|c}
\hline \multirow{2}{*}{ Treatments } & \multirow{2}{*}{ Dose (\%) } & \multicolumn{3}{|c}{ Mean percent cob infestation } \\
\cline { 3 - 5 } & & 3 DAT & 7 DAT & 12 DAT \\
\hline Dursban 20 EC & 0.1 & $4.35 \mathrm{c}$ & $5.50 \mathrm{c}$ & $6.75 \mathrm{bc}$ \\
& 0.2 & $3.90 \mathrm{~cd}$ & $4.65 \mathrm{~d}$ & $5.41 \mathrm{e}$ \\
& 0.3 & $3.50 \mathrm{~cd}$ & $4.50 \mathrm{~d}$ & $5.85 \mathrm{~d}$ \\
\hline Decis 2.5 EC & 0.1 & $5.00 \mathrm{a}$ & $6.15 \mathrm{~b}$ & $6.97 \mathrm{~b}$ \\
& 0.2 & $3.48 \mathrm{~cd}$ & $3.50 \mathrm{e}$ & $3.87 \mathrm{f}$ \\
\hline Lebaycid 50 EC & 0.3 & $1.72 \mathrm{e}$ & $1.90 \mathrm{f}$ & $2.75 \mathrm{~g}$ \\
\hline Control & 0.1 & $5.35 \mathrm{~b}$ & $5.85 \mathrm{bc}$ & $6.85 \mathrm{bc}$ \\
\hline Level of significance & 0.2 & $4.25 \mathrm{c}$ & $5.68 \mathrm{c}$ & $6.75 \mathrm{bc}$ \\
\hline CV (\%) & 0.3 & $3.80 \mathrm{~cd}$ & $4.25 \mathrm{~d}$ & $5.45 \mathrm{e}$ \\
\hline LSD value & - & $6.00 \mathrm{a}$ & $7.05 \mathrm{a}$ & $7.50 \mathrm{a}$ \\
\hline
\end{tabular}

** Different letters indicate significant differences at $1 \%$ level of probability 
The above result indicated that the percent cob infestation was significantly reduced after application of different insecticides. But the infestation level gradually increased with the time intervals of insecticides application due to decreasing toxic effects of applied insecticides.

\section{Effects of different insecticides on the reduction of extent of kernel damage and yield loss}

After harvesting the cobs, the mean number of damaged kernel was counted from each infested cob and yield loss was calculated from different treated plot shown in Table 2. The highest mean number of kernel damage (24.80) was in control plot. The highest reduction of kernel damage (2.10) was observed in $0.3 \%$ Decis treated plot followed by 3.01 and 5.02 in $0.2 \%$ Decis and $0.3 \%$ Dursban treated plots, respectively. The highest yield loss (16.64 kg/ha) was observed in control plot. The highest reduction of yield loss $(1.40 \mathrm{~kg} / \mathrm{ha})$ was observed in $0.3 \%$ Decis treated plot followed by $2.00 \mathrm{~kg} / \mathrm{ha}$ and 3.36 $\mathrm{kg} /$ ha in $0.2 \%$ Decis and $0.3 \%$ Dursban treated plots, respectively. In control plots the yield loss was higher than all other treatments.

Table 2. Reduction of kernel damage in the overall ear and yield loss after different insecticides application

\begin{tabular}{l|c|c|c}
\hline \multicolumn{1}{c}{ Treatments } & Doses (\%) & $\begin{array}{c}\text { Mean number of kernels } \\
\text { damaged in the overall ear }\end{array}$ & Yield loss (kg/ha) \\
\hline Dursban 20 EC & 0.1 & $15.50 \mathrm{~b}$ & $10.40 \mathrm{~b}$ \\
& 0.2 & $9.04 \mathrm{~cd}$ & $6.04 \mathrm{~cd}$ \\
& 0.3 & $5.02 \mathrm{ef}$ & $3.36 \mathrm{cdef}$ \\
\hline Decis 2.5 EC & 0.1 & $6.99 \mathrm{de}$ & $4.68 \mathrm{cde}$ \\
& 0.2 & $3.01 \mathrm{fg}$ & $2.00 \mathrm{ef}$ \\
& 0.3 & $2.10 \mathrm{~g}$ & $1.40 \mathrm{f}$ \\
\hline Lebaycid 50 EC & 0.1 & $17.40 \mathrm{~b}$ & $11.64 \mathrm{~b}$ \\
& 0.2 & $10.87 \mathrm{c}$ & $7.24 \mathrm{c}$ \\
\hline Control & 0.3 & $5.74 \mathrm{e}$ & $3.84 \mathrm{cdef}$ \\
\hline Level of significance & - & $24.80 \mathrm{a}$ & $16.64 \mathrm{a}$ \\
\hline CV (\%) & & $* *$ & $* * 74$ \\
\hline LSD value & & 2.526 & 0.23 \\
\hline
\end{tabular}

** Different letters indicate significant differences at $1 \%$ level of probability

The results of the findings showed that $0.2,0.3 \%$ Decis and $0.3 \%$ Dursban treated plots had significantly different percentage of reduction of cob infestation of $H$. zea from that of control plot. It was also observed that $0.3 \%$ Decis treated plot showed the lowest kernel damage and yield loss compared to other treatments. Results showed that all three insecticides gave significant control of $H$. zea in maize when compared to the control. The present results supported the findings of Hutchison et al. (2007) who studied on synthetic 
pyrethroid insecticides and found averaged only 19.3 to $37.3 \%$ control of $H$. zea. The findings of present study indicated similar reduction of corn earworm infestation by the application of pesticides of different types. Although it did not provide the total control, all the three insecticides reduced the infestation of $H$. zea to a certain level. It may be suggested that two applications of Decis $0.3 \%$ could give significantly better control than one application. Therefore, $0.3 \%$ Decis might be used to control H. zea in the maize field.

\section{REFERENCES}

Bell, J. C. and Mcgeoch, M. A. 1996. An evaluation of the pest status and research conducted on phytophagous lepidoptera on cultivated plants in South Africa. African Entomol., 4(2): 161-170.

Filho, M. M., Lucia, T. M. C-Della, Cruz, I., Guedes, R. N. C. and Galvao, J. C. C. 2002. Chlorpyrifos spraying of no-tillage corn during tasselling and its effect on damage by Helicoverpa zea (Lepidoptera: Noctuidae) and on its natural enemies. J. Appl. Entomol., 126(7/8): 422-430.

Flint, M. L. 1985. Corn Earworm, Heliothis zea, pp. 51-55. In: Integrated Pest Management for Cole Crops and Lettuce. University of California Publication 3307. Berkeley, California, USA. 112 p.

Gomez, K. A. and Gomez, A. A. 1984. Statistical Procedures for Agricultural Research. 2nd ed. A Wiley Interscience Publications. John Wiley and Sons, New York. 680 p.

Greenstone, M. H. 1995. Bollworm or budworm? Squashblot immunoassay distinguishes eggs of Helicoverpa zea and Heliothis virescence (Lepidoptera: Noctuidae). J. Econ. Entomol., 88: 213-218.

Hill, D.S. 1983. Heliothis zea (Boddie). In: Agricultural Insect Pests of the Tropics and Their Control. Cambridge, UK: Cambridge University Press. 367 p.

Hutchison, W. D., Burkness, E. C., Jensen, B., Leonard, B. R., Temple, J., Cook, D. R., Weinzierl, R. A., Foster, R. E., Rabaey, T. L. and Flood, B. R. 2007. Evidence for decreasing Helicoverpa zea susceptibility to pyrethroid insecticides in the Midwestern United States. Plant Health Progress., pp. 1-6.

Kanga, L. H. B., Plapp, Jr. F. W., Elzen, G. W., Wall, M. L. and Lopez, Jr. J. D. 1995. Monitoring for resistance to organophosphorous, carbamate, and cyclodiene insecticides in tobacco budworms adults (Lepidoptera:Noctuidae). J. Econ. Entomol., 88: 1144-1149.

Luttrell, R. G., Fitt, G. P., Ramalho, F. S. and Sugonyaev, E. S. 1994. Cotton pest management. Ann. Rev. Entomol., 39: 517-519.

Mathur, L. M. L. 1987. Bibliography of maize pests in India. AICMIP, Indian Agricultural Research Institute, New Delhi (Monograph).

Mathur, L. M. L. 1992. Insect pest management and its future in Indian maize programme. XIX International Congress of Entomology, June 27- July 4, 1992, Beijing, China.

Mueller, T. F., Harris, V. E. and Phillips, J. R. 1984. Theory of Heliothis (Lepidoptera : Noctuidae) management through reduction of the first spring generation: A critique. Environ. Entomol., 13: 625-634.

Sehgal, V. K. and Ujagir, R. 1990. Effect of synthetic pyrethroids, neem extract and other insecticides for the control of pod damage by Helicoverpa armigera (Hübner) and pod damage/yield relationships at Patnagar in northern India. Crop protection., 9: 25-32.

Sharma, H. C. 2001. Cotton Bollworm/Legume Pod Borer, Helicoverpa armigera (Hübner) (Noctuidae : Lepidoptera): Biology and Management. Crop Protection Compendium. Wallingford, UK: CAB International. $72 \mathrm{p}$. 